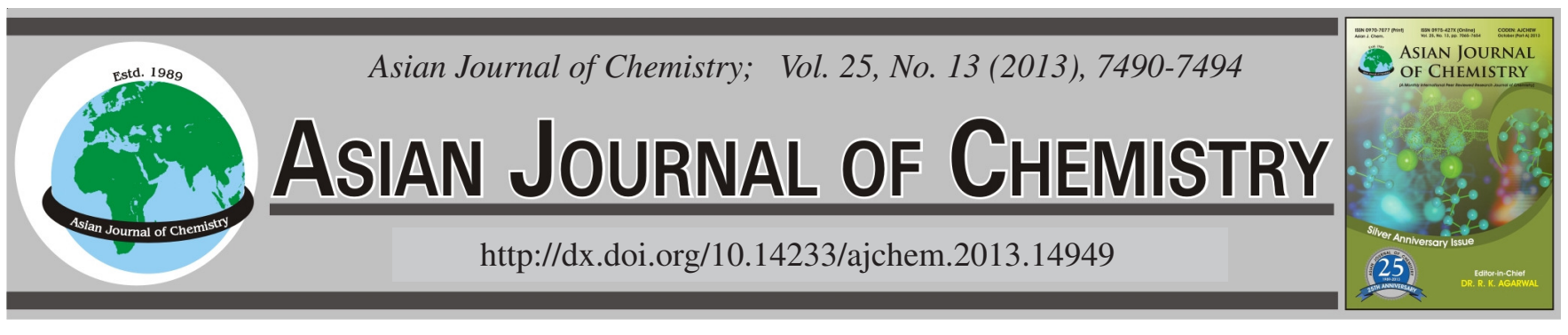

\title{
Synthesis and Crystal Structure of Chiral (1R,5R)-3-Arylidenopinones
}

\author{
YI-QIN YANG ${ }^{1}$, HAI-JUN XU ${ }^{2}$, LAN LAN ${ }^{1}$ and SHI-FA WANG ${ }^{1,2, *}$
}

${ }^{1}$ Institute of Light Industry Science and Engineering, Institute of Chemical Engineering, Nanjing Forestry University, Nanjing 210037, P.R. China ${ }_{2}^{2}$ Jiangsu Key Lab of Biomass-based green Fuels and Chemicals, College of Chemical Engineering, Nanjing Forestry University, Nanjing 210037, P.R. China

*Corresponding author: Fax: +86 25 85418873; Tel: +25 85427812; E-mail: wsfyyq@njfu.com.cn; xuhaijun@njfu.edu.cn

Three (1R,5R)-(-)3-arylideneopinones (2a, 2b and 2c) were first synthesized and characterized by IR, MS, NMR, elemental analysis and single-crystal X-ray diffraction method. The structure indicates that the compound 2a belongs to orthorhombic, space group P $2{ }_{1} 2_{1} 2_{1}$ with $\mathrm{a}=1.0378(5) \mathrm{nm}, \mathrm{b}=1.1156(6) \mathrm{nm}, \mathrm{c}=1.2775(7) \mathrm{nm}, \beta=90^{\circ} . \mathrm{V}=1.4791(13) \mathrm{nm}^{3}, \mathrm{Z}=4, \rho=1.223 \mathrm{~g} \mathrm{~cm}^{-3}, \mu=0.083 \mathrm{~mm}^{-1}, \mathrm{~F}(000)=$ 584 and final $R_{1}=0.0327, w R 2=0.0876$. The compound $\mathbf{2 b}$ belongs to trigonal, space group $\mathrm{P}_{2}$ with $\mathrm{a}=0.93024(12) \mathrm{nm}, \mathrm{b}=0.93024(12)$ $\mathrm{nm}, \mathrm{c}=1.3215(4) \mathrm{nm}, \beta=90.0^{\circ} . \mathrm{V}=0.9903(3) \mathrm{nm}^{3}, \mathrm{Z}=3, \rho=1.219 \mathrm{~g} \mathrm{~cm}^{-3}, \mu=0.079 \mathrm{~mm}^{-1}, \mathrm{~F}(000)=390$ and final $\mathrm{R}_{1}=0.0350$, wR2 $=$ 0.0912. The compound $2 \mathrm{c}$ belongs to monoclinic, space group $\mathrm{P} 2_{1}$ with $\mathrm{a}=1.20252(15) \mathrm{nm}, \mathrm{b}=0.99228(12) \mathrm{nm}, \mathrm{c}=2.3905(3) \mathrm{nm}, \beta=$ $92.769(2)^{\circ} . \mathrm{V}=2.8491(6) \mathrm{nm}^{3}, \mathrm{Z}=8, \rho=1.216 \mathrm{~g} \mathrm{~cm}^{-3}, \mu=0.254 \mathrm{~mm}^{-1}, \mathrm{~F}(000)=1104$ and final $\mathrm{R}_{1}=0.0440$, wR2 $=0.1069$.

Key Words: (1S,5S)-(-)- $\beta$-pinene, (1R,5S)-(+)-nopinone, (1R,5R)-(-)-3-arylideneno-pinones, Crystal structure, Synthesis.

\section{INTRODUCTION}

It is a well-known fact that an over exposure to solar ultraviolet radiation is harmful to human health, the major acute effects on normal human skin comprise sunburn cells, tanning, premature skin aging and an increased risk for skin cancers ${ }^{1-3}$. The steady increase in the incidence of melanoma, non-melanoma cutaneous neoplasia and preneoplasic disorders has contributed to the demand for more effective protection from the sun ${ }^{4-6}$.

Terpenoid derivatives, such as benzylidene camphor, $p$ methylbenzylidene camphor, benzylidene camphor sulfonic acid, are widely used as UV filters in cosmetics because of their stable storage, no irritation to skin, no photosensitization, low toxicity, good stability and chemical inertness and low absorption to $\operatorname{skin}^{7,8}$. However, natural camphor is expensive and the synthesized camphor exist several disadvantages including a long process of synthesis routes and severe environmental pollution. The crystal structure of such compounds are interesting and have seldom been reported. Herein, we report the synthesis and structural characterization of a chiral (1R, 5R)-3-arylidenopinones (2a-2c) which had good ultraviolet absorption characteristics by using a low cost and abundant renewable resource $\beta$-pinene as the raw material.

\section{EXPERIMENTAL}

$\mathrm{NMR}$ spectra were recorded in $\mathrm{CDCl}_{3}$ solution on a Bruker AV 400 spectrometer at $400 \mathrm{MHz}$ for ${ }^{1} \mathrm{H}$ and $100 \mathrm{MHz}$ for
${ }^{13} \mathrm{C}$, respectively. The chemical shifts were expressed in ppm ( $\delta$ scale) relative to the reference compound tetramethylsilane (TMS). Electronic impact (EI) gas chromatography-mass spectrometry (GC-MS) was conducted on an Agilent $6890 \mathrm{~N}$ GC coupled to an Agilent Technologies 5973 inert mass selective detector using a $30 \mathrm{~m} \times 0.25 \mathrm{~mm}$ i.d., $0.25 \mu \mathrm{m}$ file thickness HP-5MS capillary column (Agilent Technologies, Wilmington, DE) with helium as carrier gas $\left(36 \mathrm{~cm} / \mathrm{s}, 80^{\circ} \mathrm{C}\right.$ for $2 \mathrm{~min}$ and then programmed to $280{ }^{\circ} \mathrm{C}$ at $15^{\circ} \mathrm{C} / \mathrm{min}$ and held for $20 \mathrm{~min}$ ). A $70 \mathrm{eV}$ electron beam was employed for sample ionization. GC analyses were performed on an Agilent 6890 GC equipped with a flame ionization detector (FID) using a $30 \mathrm{~m} \times 0.32$ mm i.d., $0.25 \mu \mathrm{m}$ file thickness HP-5 capillary column with nitrogen as carrier gas $\left(38 \mathrm{~cm} / \mathrm{s}, 80{ }^{\circ} \mathrm{C}\right.$ for $2 \mathrm{~min}$ and then programmed to $280{ }^{\circ} \mathrm{C}$ at $10^{\circ} \mathrm{C} / \mathrm{min}$ and held for $20 \mathrm{~min}$ ) in the split mode and the split ratio was 50:1. Fourier-transform infrared (FT-IR) spectra of samples were recorded from potassium bromide disks prepared with each crystalline sample on a Nicolet 380 FT-IR spectrophotometer in the scan range of $4000-400 \mathrm{~cm}^{-1}$. Melting points and specific rotation were measured using X-6 microscopic melting point apparatus and Shanghai Spoif W22-2S automatic polarimeter. The raw material $\beta$-pinene with a purity of $98.1 \%(\mathrm{GC})$ and $[\alpha]_{\mathrm{D}}{ }^{25}-21.1^{\circ}$ (c $=1.0, \mathrm{CHCl}_{3}$ ) was purchased from Deqing Forest Chemical Plant of China. Flash column chromatography was carried out on silica gel 60 (230-400 mesh). All reactions were performed 
under a nitrogen atmosphere with magnetic stirring and the syntheses of 3 -arylidenenopinones from $\beta$-pinene were shown in Scheme-I.
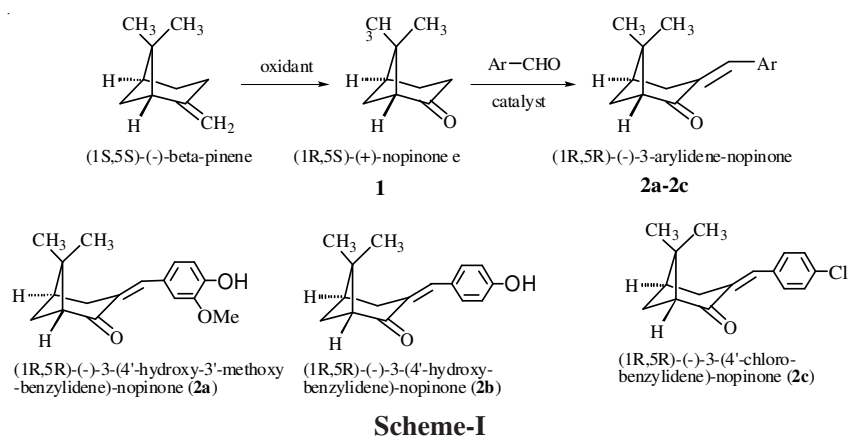

Synthesis

(+)-Nopinone (1): Nopinone was prepared by $\beta$-pinene oxidation using acidic potassium permanganate. A $500 \mathrm{~mL}$ dried three-necked flask equipped with a thermometer, condenser and stirrer was charged with acetone $100 \mathrm{~mL}, 2 \mathrm{~mol} / \mathrm{L}$ $\mathrm{H}_{2} \mathrm{SO}_{4} 15 \mathrm{~mL}$ and $\beta$-pinene $50 \mathrm{~g}$ and cooled with ice bath to about $15{ }^{\circ} \mathrm{C} .87 \mathrm{~g}$ of $\mathrm{KMnO}_{4}$ fully crashed was added in portions within 1 1.5 h. The ice bath was removed after complete addition of $\mathrm{KMnO}_{4}$ and the reaction was kept at room temperature for another 5-6 h. The reaction was monitored by $\mathrm{GC}$ until the peak of $\beta$-pinene was disappeared. The resulting mixture was filted with a sand-core funnel to remove the solid $\mathrm{MnO}_{2}$ and was washed with acetone $(2 \times 40 \mathrm{~mL})$. The filtrate was concentrated by a rotor evaporator to recover acetone and the bottom residue was diluted with $100 \mathrm{~mL}$ of hexane. The diluted residue was washed with saturated brine to neutral and the organic layer was dried over $\mathrm{Na}_{2} \mathrm{SO}_{4}$ and then was distilled to collect the fraction at $100 \sim 102{ }^{\circ} \mathrm{C} / 266 \mathrm{kPa}$, a colourless oily liquid with a yield over $83.9 \%$, purity $95.04 \%$ (GC), specific rotation $[\alpha]_{\mathrm{D}}^{25}+27.3^{\circ}\left(\mathrm{c}=1.0, \mathrm{CHCl}_{3}\right)$.

(1R, 5R)-(-)-3-(4-hydroxy-3-methoxybenzylidene) nopinone (2a): A $100 \mathrm{~mL}$ dried flask fitted with a agitator, thermometer and condensor was charged with (+)-nopinone $(1.38 \mathrm{~g}, 0.01 \mathrm{~mol})$, vanillin $(1.824 \mathrm{~g}, 0.012 \mathrm{~mol})$ and $3 \mathrm{~g}$ of powderd potassium tert-butoxide in $30 \mathrm{~mL}$ of toluene under a nitrogen atmosphere and the resulting mixture was refluxed for 10 12 h until the main product reached $70 \sim 75 \%$ and the byproduct was controlled within 10 15\% (monitored with GC) and then $15 \mathrm{~mL}$ of water was added. The mixture was separated into two layers and the organic layer was washed with water and brine to neutrality, dried over $\mathrm{Na}_{2} \mathrm{SO}_{4}$ and concentrated to afford the yellow crude product, which was purified by recrystallization in mixed solvent containing 10 $\mathrm{mL}$ of acetone and $0.5 \mathrm{~mL}$ of ethanol for several days at room temperature to afford $1.044 \mathrm{~g}(3.84 \mathrm{mmol}, 38.4 \%$ isolated yield, purity $95.3 \%$ ) of compound $\mathbf{2 a}$ as a colourless transparent crystal, m.p. $173.5-174.2{ }^{\circ} \mathrm{C},[\alpha]-44.7^{\circ}(\mathrm{c}=0.32$, $\mathrm{CHCl}_{3}$ ). ${ }^{1} \mathrm{H} \mathrm{NMR}\left(400 \mathrm{MHz}, \mathrm{CDCl}_{3}\right.$ ): $\delta$ (ppm) 0.929-1.379 $\left(\mathrm{d}, 6 \mathrm{H},-\mathrm{CH}_{3}\right), 1.500-1.520\left(\mathrm{~d}, 1 \mathrm{H},-\mathrm{CH}_{2}\right), 2.368-2.379(\mathrm{~m}$, $\left.1 \mathrm{H},-\mathrm{CH}_{2}\right), 2.609-2.633(\mathrm{~m}, 1 \mathrm{H},-\mathrm{CH}), 2.681-2.704(\mathrm{t}, 1 \mathrm{H}$, $-\mathrm{CH}), 2.951-2.972\left(\mathrm{~s}, 2 \mathrm{H},-\mathrm{CH}_{2}\right), 7.644-7.653(\mathrm{~s}, 1 \mathrm{H}, \mathrm{C}=\mathrm{CH}-$ C), $3.921\left(\mathrm{~s}, 3 \mathrm{H},-\mathrm{OCH}_{3}\right), 6.056(\mathrm{~s}, 1 \mathrm{H},-\mathrm{OH}), 6,955-6.972(\mathrm{~d}$, 1H, CH), 7.095-7.099 (s, 1H, CH), 7.189-7.209 (d, 1H, CH); ${ }^{13} \mathrm{C} \mathrm{NMR}\left(100 \mathrm{MHz}, \mathrm{CDCl}_{3}\right): \delta$ (ppm) 21.58, 26.18, 27.56,
$30.95,39.49,55.82,55.91,113.61,114.66,124.84,128.29$, 130.16, 135.90, 203.58; FT-IR ( KBr, $\left.v_{\max }, \mathrm{cm}^{-1}\right): 3238 \mathrm{v}(\mathrm{O}-\mathrm{H})$, 2966-2901 v(C-H), $1674 \mathrm{v}(\mathrm{C}=\mathrm{O}), 1593-1440\left(\mathrm{C}_{6} \mathrm{H}_{3^{-}}, \mathrm{v}_{\text {as C}=\mathrm{C}}\right)$,

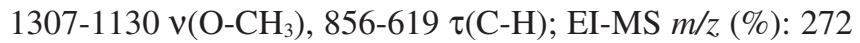
$\left(\mathrm{M}^{+}, 100\right), 257$ (19), 229 (18), 203 (30), 162 (26), 137 (24), 115 (21), 91 (20), 83 (16), 55 (33), 41 (19).

(1R,5R)-(-)-3-(4-hydroxybenzylidene) nopinone (2b): A $100 \mathrm{~mL}$ dried flask equippedd with a agitator, thermometer and condensor was charged with (+)-nopinone $(1.380 \mathrm{~g}, 0.01$ mol), $p$-hydroxybenzaldehyde $(1.83 \mathrm{~g}, 0.015 \mathrm{~mol})$ and $3.0 \mathrm{~g}$ of powderd potassium tert-butoxide in $30 \mathrm{~mL}$ of tert-butanol under a nitrogen atmosphere and the resulting mixture was refluxed for 7 8 $\mathrm{h}$ until the conversion ratio of nopinone reached over $95 \%$ (monitored with GC) and then $10 \mathrm{~mL}$ of water was added. The mixture was extracted with ethyl acetate $(3 \times 10 \mathrm{~mL})$ and the combined organic layers were washed with water and saturated brine to neutrality, dried over $\mathrm{Na}_{2} \mathrm{SO}_{4}$ and concentrated to afford the yellow crude product, which was purified by recrystallization in $10 \mathrm{~mL}$ of acetone for 3 days at room temperature to provide $1.88 \mathrm{~g}(7.76 \mathrm{mmol}, 77.6 \%$ isolated yield, purity of $97.4 \%$ ) of compound $\mathbf{2 b}$ as a colourless transparent crystal, m.p. $199.6-200.6^{\circ} \mathrm{C},[\alpha]_{\mathrm{D}}{ }^{25}-56.3^{\circ}(\mathrm{c}=0.6$, $\mathrm{CHCl}_{3}$ ). ${ }^{1} \mathrm{H}$ NMR (400 MHz, $\mathrm{CDCl}_{3}$ ): $\delta$ (ppm) 0.929-1.378 $\left(\mathrm{d}, 6 \mathrm{H},-\mathrm{CH}_{3}\right), 1.496-1.531\left(\mathrm{~d}, 1 \mathrm{H},-\mathrm{CH}_{2}\right), 2.374-2.384(\mathrm{~m}$, $\left.1 \mathrm{H},-\mathrm{CH}_{2}\right), 2.587-2.641(\mathrm{~m}, 1 \mathrm{H},-\mathrm{CH}), 2.661-2.730(\mathrm{t}, 1 \mathrm{H}$, $-\mathrm{CH}), 2.948-2.956$ (s, 2H - $\left.\mathrm{CH}_{2}\right), 7.690$ (s, 1H, C=CH-C), 6.908(m, 1H, -OH), 7.312-7.601 (m, 2H, CH), 7.573-7.601 $(\mathrm{d}, 2 \mathrm{H}, \mathrm{CH}) ;{ }^{13} \mathrm{C}$ NMR $\left(100 \mathrm{MHz}, \mathrm{CDCl}_{3}\right): \delta(\mathrm{ppm}) 21.63$, 26.19, 27.59, 29.69, 31.00, 39.47, 55.86, 115.78, 128.14, 129.84, 132.96, 136.23, 157.17, 204.92; FT-IR (KBr, $\left.v_{\max }, \mathrm{cm}^{-1}\right)$ : $3378 v(\mathrm{O}-\mathrm{H}), 2962-2911 \mathrm{v}(\mathrm{C}-\mathrm{H}), 1669 \mathrm{v}(\mathrm{C}=\mathrm{O}), 1607 \sim 1469$ $\left(\mathrm{C}_{6} \mathrm{H}_{4^{-}}, \mathrm{V}_{\text {as C}=\mathrm{C}}\right), 987-647\left(\mathrm{C}_{6} \mathrm{H}_{4^{-}}, \tau_{\mathrm{C}-\mathrm{H}}\right)$; EI-MS $\mathrm{m} / \mathrm{z}(\%): 242$ $\left(\mathrm{M}^{+}, 100\right), 227\left(\mathrm{M}^{+}-15,31\right), 199\left(227-\mathrm{C}_{2} \mathrm{H}_{4}, 42\right), 186$ (22), 171 (47), 132 (56), 107 (54), 83 (35), 55 (53), 41(34).

$(1 \mathrm{R}, 5 \mathrm{R})-(-)-3-(4-c h l o r o b e n z y l i e n e)$ nopinone (2c): A $100 \mathrm{~mL}$ dried flask fitted with a agitator, thermometer and condensor was charged with (+)-nopinone (1.38 g, $0.01 \mathrm{~mol})$, p-chlorobenzaldehyde $(1.68 \mathrm{~g}, 0.012 \mathrm{~mol})$ and $3 \mathrm{~g}$ of powderd sodium mehoxide in $30 \mathrm{~mL}$ of tertiary butanol under a nitrogen atmosphere and the resulting mixture was refluxed for 5-8 h until the conversion ratio of nopinone reached $100 \%$ and 15 $\mathrm{mL}$ of water was added and then extracted with ethyl acetate for three times $(3 \times 15 \mathrm{~mL})$. The combined organic layer was washed with water and brine to neutrality, dried over $\mathrm{Na}_{2} \mathrm{SO}_{4}$ and concentrated to afford the deep yellow crude product, which was purified by recrystallization in mixed solvent containing $10 \mathrm{~mL}$ of acetone and $0.5 \mathrm{~mL}$ of ethanol for several days at room temperature to afford $2.223 \mathrm{~g}(8.55 \mathrm{mmol}, 85.5 \%$ isolated yield, purity $97.8 \%$ ) of compound $\mathbf{2 c}$ as a colourless transparent crystal, m.p. $109.7-110.7^{\circ} \mathrm{C},[\alpha]_{\mathrm{D}}{ }^{25}-22.88^{\circ}(\mathrm{c}=$ $\left.0.31, \mathrm{CCl}_{3}\right) .{ }^{1} \mathrm{H} \mathrm{NMR}\left(400 \mathrm{MHz}, \mathrm{CDCl}_{3}\right)$ : $\delta(\mathrm{ppm}) 0.921-1.381$ $\left(\mathrm{d}, 6 \mathrm{H},-\mathrm{CH}_{3}\right), 1.484-1.505\left(\mathrm{~d}, 1 \mathrm{H},-\mathrm{CH}_{2}\right), 2.356-2.374(\mathrm{~m}$, $\left.1 \mathrm{H},-\mathrm{CH}_{2}\right), 2.618-2.651(\mathrm{~m}, 1 \mathrm{H},-\mathrm{CH}), 2.694-2.717(\mathrm{t}, 1 \mathrm{H}$, -CH), 2.930-2.941 (t, 2H, $-\mathrm{CH}_{2}$ ), 7.636-7.645 (t, 1H, C=CHC), 7.362-7.384 (t, 2H, CH), 7.499-7.516 (t, 2H, CH); ${ }^{13} \mathrm{C} \mathrm{NMR}$ $\left(100 \mathrm{MHz}, \mathrm{CDCl}_{3}\right.$ ): $\delta$ (ppm) 21.55, 26.12, 27.36, 30.78, 39.29, 40.82, 55.78, 128.73, 131.78, 133.10, 134.10, 134.18, 134.74, 202.91; FT-IR $\left(\mathrm{KBr}, v_{\max }, \mathrm{cm}^{-1}\right)$ : 2984-2874 v(C-H), 1686 
TABLE-1

CRYSTALLOGRAPHIC DATA AND STRUCTURE REFINEMENT RESULTS FOR 2a-2c

\begin{tabular}{|c|c|c|c|}
\hline Compound & $2 \mathbf{a}$ & $2 \mathbf{b}$ & $2 c$ \\
\hline Empirical formula & $\mathrm{C}_{17} \mathrm{H}_{20} \mathrm{O}_{3}$ & $\mathrm{C}_{16} \mathrm{H}_{18} \mathrm{O}_{2}$ & $\mathrm{C}_{16} \mathrm{H}_{17} \mathrm{OCl}$ \\
\hline Formular weight & 272.33 & 242.30 & 260.75 \\
\hline Temperature $[\mathrm{K}]$ & $296(2)$ & 296(2) K & $296(2)$ \\
\hline Wavelength $(\AA)$ & 0.71073 & 0.71073 & 0.71073 \\
\hline Crystal system & Orthorhombic & Trigonal & Monoclinic \\
\hline space group & $\mathrm{P} 2_{1} 2_{1} 2_{1}$ & $\mathrm{P} 3_{2}$ & $\mathrm{P} 2_{1}$ \\
\hline \multicolumn{4}{|l|}{ Unit cell dimension } \\
\hline $\mathrm{a}(\AA)$ & $10.378(5)$ & $9.3024(12)$ & $12.0252(15)$ \\
\hline $\mathrm{b}(\AA)$ & $11.156(6)$ & $9.3024(12)$ & $9.9228(12)$ \\
\hline$c(\AA)$ & $12.775(7)$ & $13.215(4)$ & $23.905(3)$ \\
\hline$\beta\left({ }^{\circ}\right)$ & 90 & 90 & $92.769(2)$ \\
\hline Volume $\left[\AA^{3}\right]$ & $1479.1(13)$ & $990.3(3)$ & 2849.1(6) \\
\hline $\mathrm{z}$ & 4 & 3 & 8 \\
\hline$\rho($ calc $)\left(g / \mathrm{cm}^{3}\right)$ & 1.223 & 1.219 & 1.216 \\
\hline Absorption Coefficient & 0.083 & 0.079 & 0.254 \\
\hline $\mathrm{F}(000)$ & 584 & 390 & 1104 \\
\hline Crystal size (mm) & $0.20 \times 0.20 \times 0.10$ & $0.15 \times 0.15 \times 0.10$ & $0.20 \times 0.15 \times 0.10$ \\
\hline \multirow[t]{3}{*}{ Limiting indices } & $-12<=\mathrm{h}<=12$ & $-11<=\mathrm{h}<=11$ & $-14<=\mathrm{h}<=13$ \\
\hline & $-13<=\mathrm{k}<=12$ & $-11<=\mathrm{k}<=11$ & $-11<=\mathrm{k}<=12$ \\
\hline & $-15<=1<=15$ & $-16<=1<=15$ & $-29<=1<=29$ \\
\hline Reflections collected/ unique & $10742 / 2825[\mathrm{R}(\mathrm{int})=0.0312]$ & $7385 / 1288[\mathrm{R}(\mathrm{int})=0.0254]$ & $21132 / 9917[\mathrm{R}(\mathrm{int})=0.0273]$ \\
\hline Max. and min. transmission & 0.984 and 0.992 & 0.988 and 0.992 & 0.955 and 0.975 \\
\hline Refinement method & Full-matrix least-squares on $\mathrm{F}^{2}$ & Full-matrix least-squares on $\mathrm{F}^{2}$ & Full-matrix least-squares on $\mathrm{F}^{2}$ \\
\hline Data/restraints/parameters & $2825 / 0 / 182$ & $1288 / 1 / 167$ & $9917 / 1 / 649$ \\
\hline Goodness-of-fit on $\mathrm{F}^{2}$ & 1.013 & 1.094 & 1.026 \\
\hline Final $R$ indices $[\mathrm{I}>2 \sigma(\mathrm{I})]$ & $\mathrm{R} 1=0.0327, w \mathrm{R} 2=0.0876$ & $\mathrm{R} 1=0.0350, \mathrm{wR} 2=0.0912$ & $\mathrm{R} 1=0.0440, w \mathrm{R} 2=0.1069$ \\
\hline $\mathrm{R}$ indices (all data) & $\mathrm{R} 1=0.0365, \mathrm{wR} 2=0.0906$ & $\mathrm{R} 1=0.0359, \mathrm{wR} 2=0.0918$ & $\mathrm{R} 1=0.0718, \mathrm{wR} 2=0.1178$ \\
\hline Absolute structure parameter & $0.2(10)$ & $0.2(15)$ & $-0.03(5)$ \\
\hline
\end{tabular}

$v(\mathrm{C}=\mathrm{O}), 1686-1407\left(\mathrm{C}_{6} \mathrm{H}_{4^{-}}, \mathrm{v}_{\text {as } \mathrm{C}=\mathrm{C}}\right), 979-686\left(\mathrm{C}_{6} \mathrm{H}_{4^{-}}, \tau_{\mathrm{C}-\mathrm{H}}\right)$; EI-MS m/z (\%): $260\left(\mathrm{M}^{+}, 97\right), 245$ (54), 217 (54), 204 (21), 189 (39), 165 (31), 150 (48), 141 (47), 125 (48), 115 (100), 83 (78), 55 (89).

Crystal structure determination: Crystallographic data of 2a-2c were collected at $292 \mathrm{~K}$ on a Bruker SMART APEX CCD diffractometer with graphite-monochromatized $\mathrm{MoK}_{\alpha}$ radiation $(\lambda=0.071073 \mathrm{~nm})$. An empirical absorption correction was applied. The structures were solved by the direct method and refined using the SHELXL-97 software ${ }^{9}$. All nonhydrogen atoms were refined by full-matrix least-squares method on $\mathrm{F}^{2}$ with anisotropy thermal parameters, while all hydrogen atoms were refined in calculated positions, assigned isotropic thermal parameters and allowed to ride their parent atoms. Crystallographic data and structure refinement results are summarized in Table- 1 .

\section{RESULTS AND DISCUSSION}

The compounds $\mathbf{2 a - 2 c}$ are light yellow crystals and stable in air at room temperature. The ${ }^{1} \mathrm{H}$ NMR, MS and elemental analysis for these three compounds are all in good agreement with the assumed structure. In order to obtain a definitive structural proof of the 3-arylideneopinones and stereochemical information, the single crystal X-ray diffraction study was undertaken.

The compound $\mathbf{2 a}$ crystallizes in the orthorhombic space group $\mathrm{P} 2{ }_{1} 2_{1} 2_{1}$. The molecular structure of the compound $\mathbf{2} \mathbf{a}$ is shown in Fig. 1, which displays the $\mathbf{E}$ conformataion with respect to the $\mathrm{C}=\mathrm{C}$ double bond mainly due to the intramolecular repulsive interaction between $\mathrm{O} 3$ and H6A. The absolute

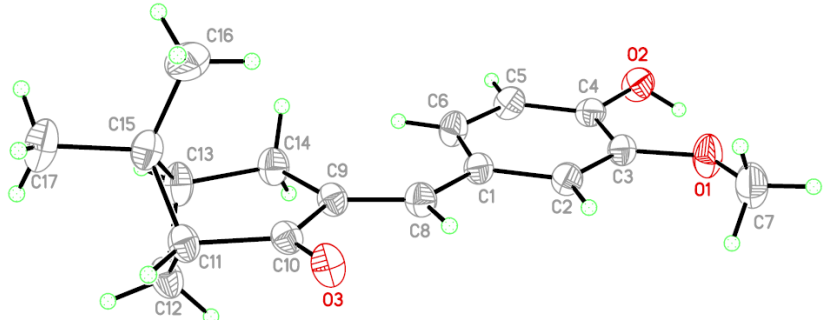

Fig. 1. Molecular structure of the compound 2a

configuration of $\mathrm{C} 11$ and $\mathrm{C} 13$ was established as R. The selected bond lengths and bond angles are listed in Table-2. The $\mathrm{C}-\mathrm{C}$ bond lengths within the phenyl ring are normal in the range from $0.1380(2)$ to $0.1409(2) \mathrm{nm}$ with normal angles close to $120^{\circ}$ with the exception of the the angle (C2-C1-C6, 117.61(13). The cyclohexanone ring in the bicyclic ring system adopts a flattened half chair conformation that is constrained by the dimethyl substituted cyclobutane ring. The dihedral angle between the plane consisting of C9-C10-C11-C13-C14 and the phenyl ring is 5.04 $(0.10)^{\circ}$, which indicates the two planes are nearly coplanar. In addition, the aromatic ring bonded to the $\mathrm{C} 8$ is coplanar around the $\mathrm{C} 8-\mathrm{C} 9$ bond with a torsion angle C6-C1-C8-C9 of 2.6 (3) ${ }^{\circ}$, which suggests a conjugation with the remaining part of the system of C8-C9-C10-O2. The bond length of C8-C9 and C10$\mathrm{O} 3$ are $0.1348(2)$ and $0.12248(17) \mathrm{nm}$ respectively which indicates a doule-bond character, but they are slight longer than that of lack conjugation of the double bond ${ }^{10}$. However, the C1-C8 $(0.1463(2)$ is shorter than the normal C-C single bond, suggesting a big conjugation system exists in the double bond and phenyl ring and the electronic transfer occurs from the aromatic ring the 
TABLE-2

SELECTED BOND LENGTHS $(\AA)$ AND BOND ANGLES $\left({ }^{\circ}\right)$ FOR THE COMPOUND $2 a$

\begin{tabular}{cccccc}
\hline Bond & Distance $(\AA)$ & Bond & Distance $(\AA)$ & Bond & Distance $(\AA)$ \\
\hline C1-C2 & $1.409(2)$ & C9-C10 & $1.501(2)$ & C13-C15 & $1.566(2)$ \\
C2-C3 & $1.385(2)$ & C9-C14 & $1.522(2)$ & C15-C17 & $1.542(2)$ \\
C3-C4 & $1.402(2)$ & C10-C11 & $1.505(2)$ & O1-C3 & $1.3708(19)$ \\
C4-C5 & $1.380(2)$ & C11-C12 & $1.558(2)$ & O1-C7 & $1.426(2)$ \\
C5-C6 & $1.389(2)$ & C11-C15 & $1.565(2)$ & O2-C4 & $1.3621(18)$ \\
C1-C6 & $1.401(2)$ & C12-C13 & $1.527(3)$ & O3-C10 & $1.2248(17)$ \\
C1-C8 & $1.463(2)$ & C13-C14 & $1.528(2)$ & - & - \\
C8-C9 & $1.348(2)$ & C15-C16 & $1.520(3)$ & - & - \\
Angle & $\left({ }^{\circ}\right)$ & Angle & $\left({ }^{\circ}\right)$ & Angle & $\left({ }^{\circ}\right)$ \\
C3-C2-C1 & $121.69(14)$ & O2-C4-C5 & $118.57(14)$ & C14-C13-C15 & $111.09(13)$ \\
C2-C3-C4 & $119.62(14)$ & O1-C3-C2 & $125.92(14)$ & C9-C14-C13 & $111.53(13)$ \\
C5-C4-C3 & $119.22(13)$ & C3-O1-C7 & $117.89(13)$ & C10-C9-C14 & $116.07(13)$ \\
C4-C5-C6 & $121.34(15)$ & O3-C10-C9 & $124.09(13)$ & C17-C15-C11 & $110.86(15)$ \\
C5-C6-C1 & $120.51(15)$ & C8-C9-C10 & $117.42(13)$ & C11-C15-C13 & $85.05(12)$ \\
C6-C1-C2 & $117.61(13)$ & C9-C10-C11 & $115.14(12)$ & C16-C15-C17 & $109.00(16)$ \\
C6-C1-C8 & $125.35(13)$ & C10-C11-C12 & $107.25(12)$ & C16-C15-C13 & $119.20(16)$ \\
C2-C1-C8 & $116.99(13)$ & C10-C11-C15 & $109.66(12)$ & C9-C14-C13 & $111.53(13)$ \\
C9-C8-C1 & $132.17(14)$ & C14-C13-C12 & $109.33(15)$ & C17-C15-C13 & $112.33(15)$ \\
\hline
\end{tabular}

$\mathrm{O}=\mathrm{C}-\mathrm{C}=\mathrm{C}$ system. The other bond lengths and angels for the bicyclic ring fragments are consistent with those previously reported values ${ }^{10}$. A srong $\mathrm{O}-\mathrm{H}$-..O intermolecular hydrogen-bond interaction is observed in the molecule structure, which forms an infinite one dimension zigzag chain structure (Table-3, Fig. 2).

The compound $\mathbf{2} \mathbf{b}$ crystallizes in the orthorhombic space group P32. The molecular structure of the compound $\mathbf{2 b}$ is shown in Fig. 3. The selected bond lengths and bond angles are listed in Table-4. Bond lengths and angles observed in $\mathbf{2 b}$

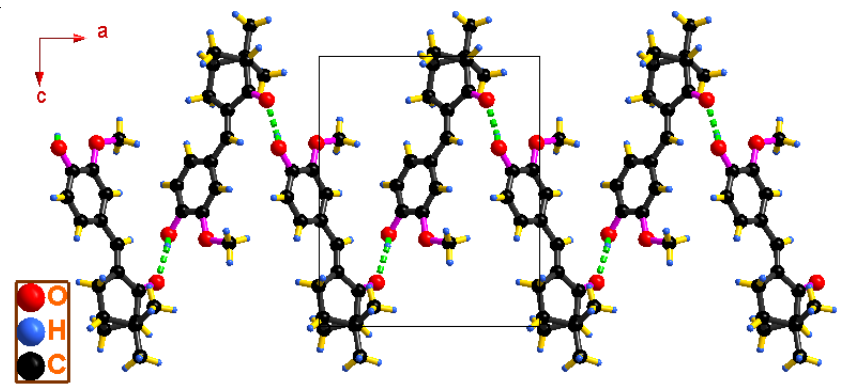

Fig. 2. Molecular one-dimensional chain hydrogen-bond structure of the compound $\mathbf{2 a}$

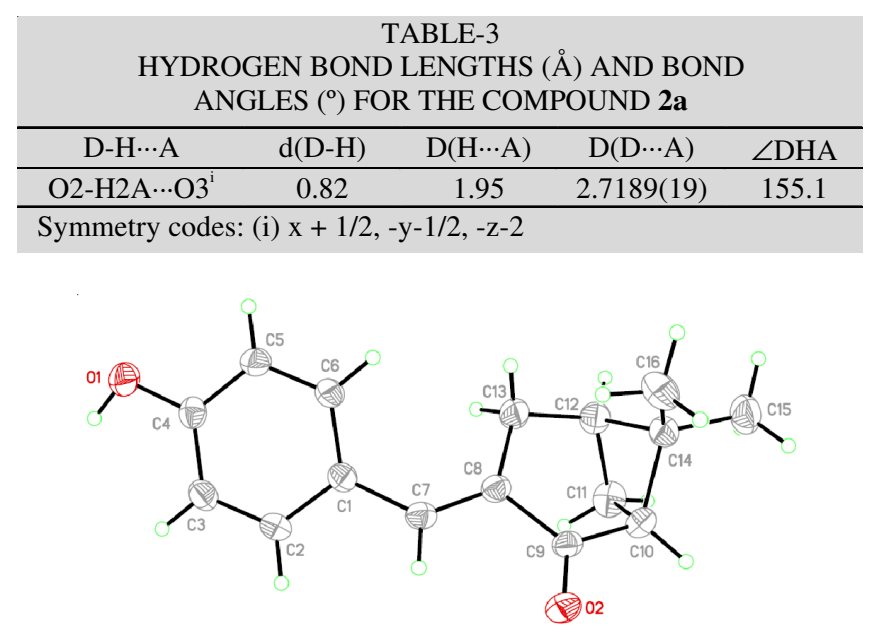

Fig. 3. Molecular structure of the compound $\mathbf{2 b}$

are in normal ranges and similar to the corresponding values in 2a. However, the phenyl ring is oriented with the respect to the plane consisting of $\mathrm{C} 8-\mathrm{C} 9-\mathrm{C} 10-\mathrm{C} 12-\mathrm{C} 3$ at a dihedral angle of $42.94(0.07)^{\circ}$. In addition, a torsion angle of C6-C1-C7-C8

TABLE-4

SELECTED BOND LENGTHS $(\AA)$ AND BOND ANGLES $\left(^{\circ}\right)$ FOR THE COMPOUND 2b

\begin{tabular}{|c|c|c|c|c|c|}
\hline Bond & Distance $(\AA)$ & Bond & Distance $(\AA)$ & Bond & Distance $(\AA)$ \\
\hline $\mathrm{C} 1 \mathrm{C} 2$ & $1.399(3)$ & C7-C8 & $1.342(3)$ & $\mathrm{C} 11-\mathrm{C} 12$ & $1.533(4)$ \\
\hline $\mathrm{C} 2-\mathrm{C} 3$ & $1.370(3)$ & $\mathrm{O} 1-\mathrm{C} 4$ & $1.361(3)$ & C12-C14 & $1.563(3)$ \\
\hline $\mathrm{C} 3-\mathrm{C} 4$ & $1.390(3)$ & $\mathrm{O} 2-\mathrm{C} 9$ & $1.230(3)$ & C13-C12 & $1.522(3)$ \\
\hline C5-C6 & $1.374(3)$ & C9-C10 & $1.495(3)$ & C16-C14 & $1.510(4)$ \\
\hline C1-C6 & $1.400(3)$ & $\mathrm{C} 10-\mathrm{C} 11$ & $1.551(3)$ & C14-C15 & $1.538(4)$ \\
\hline $\mathrm{C} 7-\mathrm{C} 1$ & $1.459(3)$ & $\mathrm{C} 10-\mathrm{C} 14$ & $1.568(3)$ & - & - \\
\hline $\mathrm{C} 3-\mathrm{C} 2-\mathrm{C} 1$ & $121.9(2)$ & C7-C8-C9 & $117.41(18)$ & C8-C13-C12 & $111.30(18)$ \\
\hline $\mathrm{C} 2-\mathrm{C} 3-\mathrm{C} 4$ & $120.2(2)$ & C8-C9-C10 & $115.44(17)$ & C9-C8-C13 & $115.78(18)$ \\
\hline C5-C4-C3 & $119.0(2)$ & C9-C10-C11 & $106.91(19)$ & C16-C14-C10 & $118.0(2)$ \\
\hline C6-C5-C4 & $120.5(2)$ & C9-C10-C14 & $110.16(19)$ & C16-C14-C12 & $119.2(2)$ \\
\hline C5-C6-C1 & $121.45(19)$ & C13-C12-C11 & $110.0(2)$ & C15-C14-C10 & $111.2(2)$ \\
\hline C2-C1-C6 & $116.9(2)$ & C13-C12-C14 & $110.92(19)$ & C16-C14-C15 & $109.8(2)$ \\
\hline C8-C7-C1 & $129.19(19)$ & C12-C14-C10 & $85.11(18)$ & $\mathrm{O} 2-\mathrm{C} 9-\mathrm{C} 8$ & $121.6(2)$ \\
\hline
\end{tabular}


TABLE-6

SELECTED BOND LENGTHS $(\AA)$ AND BOND ANGLES $\left({ }^{\circ}\right)$ FOR THE COMPOUND $2 c$

\begin{tabular}{cccccc}
\hline Bond & Distance $(\AA)$ & Bond & Distance $(\AA)$ & Bond & Distance $(\AA)$ \\
\hline C1-C2 & $1.395(4)$ & C7-C8 & $1.338(4)$ & C12-C14 & $1.512(4)$ \\
C2-C3 & $1.372(4)$ & C8-C9 & $1.495(4)$ & C13-C15 & $1.548(5)$ \\
C3-C4 & $1.362(4)$ & C9-C10 & $1.484(4)$ & C13-C16 & $1.521(5)$ \\
C4-C5 & $1.361(4)$ & C10-C11 & $1.551(5)$ & C8-C14 & $1.526(4)$ \\
C5-C6 & $1.374(4)$ & C10-C13 & $1.554(4)$ & O1-C9 & $1.209(3)$ \\
C1-C6 & $1.385(4)$ & C11-C12 & $1.523(4)$ & O2-C30 & $1.217(3)$ \\
C7-C1 & $1.460(4)$ & C13-C12 & $1.549(5)$ & O3-C46 & $1.213(3)$ \\
C11-C4 & $1.740(3)$ & C12-C20 & $1.743(3)$ & O4-C57 & $1.218(3)$ \\
C13-C36 & $1.740(3)$ & C14-C52 & $1.736(3)$ & C17-C18 & $1.394(4)$ \\
C18-C19 & $1.380(4)$ & C20-C19 & $1.374(4)$ & C20-C21 & $1.371(4)$ \\
C22-C21 & $1.374(4)$ & C22-C17 & $1.389(4)$ & C23-C17 & $1.461(4)$ \\
C23-C24 & $1.344(4)$ & C24-C25 & $1.514(4)$ & C26-C25 & $1.517(3)$ \\
C26-C27 & $1.532(4)$ & C28-C27 & $1.544(4)$ & C26-C29 & $1.548(4)$ \\
C28-C29 & $1.554(4)$ & C30-C28 & $1.485(4)$ & C29-C32 & $1.532(4)$ \\
C29-C31 & $1.524(5)$ & C24-C30 & $1.503(4)$ & C39-C40 & $1.340(3)$ \\
C56-C55 & $1.344(3)$ & - & - & - & - \\
\hline Angle & $\left({ }^{\circ}\right)$ & Angle & $\left({ }^{\circ}\right)$ & Angle & $\left({ }^{\circ}\right)$ \\
C1-C2-C3 & $121.3(3)$ & C8-C7-C1 & $130.3(3)$ & C16-C13-C15 & $110.1(3)$ \\
C2-C3-C4 & $119.9(3)$ & C7-C8-C9 & $118.1(2)$ & C15-C13-C10 & $115.9(3)$ \\
C3-C4-C5 & $120.5(3)$ & C10-C9-C8 & $115.2(3)$ & C16-C13-C12 & $112.7(4)$ \\
C4-C5-C6 & $119.9(3)$ & C9-C10-C11 & $107.3(3)$ & C12-C14-C8 & $110.7(2)$ \\
C5-C6-C1 & $121.5(3)$ & C9-C10-C13 & $110.6(2)$ & C9-C8-C14 & $115.9(2)$ \\
C6-C1-C2 & $116.9(3)$ & C12-C11-C10 & $86.5(3)$ & O1-C9-C8 & $122.9(3)$ \\
C6-C1-C7 & $124.4(3)$ & C12-C13-C10 & $85.5(2)$ & C3-C4-C11 & $119.9(3)$ \\
O2-C30-C24 & $123.1(3)$ & C19-C20-C12 & $119.2(3)$ & O3-C46-C40 & $123.1(2)$ \\
C35-C36-C13 & $119.9(2)$ & O4-C57-C56 & $123.5(2)$ & C51-C52-C14 & $120.0(2)$ \\
\hline
\end{tabular}

is $-31.92(1)^{\mathrm{o}}$. All these parameters indicate that there is lack of conjugation in the system of C7-C8-C9-O2. However, there is also a strong intermolecular O-H $\cdots$ O hydrogen bond (Table-5) between the carbonyl and hydroxy groups which link the molecules into a two-dimesional network, in which they may be effective in the stabilization of the structure.

\begin{tabular}{|c|c|c|c|c|}
\hline \multicolumn{5}{|c|}{$\begin{array}{c}\text { TABLE-5 } \\
\text { HYDROGEN BOND LENGTHS (̊) AND BOND } \\
\text { ANGLES }\left({ }^{\circ}\right) \text { FOR THE COMPOUND } \mathbf{2 b}\end{array}$} \\
\hline D-H $\cdots A$ & $\mathrm{~d}(\mathrm{D}-\mathrm{H})$ & $\mathrm{D}(\mathrm{H} \cdots \mathrm{A})$ & $\mathrm{D}(\mathrm{D} \cdots \mathrm{A})$ & $\angle \mathrm{DHA}$ \\
\hline $\mathrm{O} 1-\mathrm{H} 1 \mathrm{~A} \cdots \mathrm{O} 2^{\mathrm{i}}$ & $0.88(5)$ & $1.91(5)$ & $2.775(2)$ & $169(4)$ \\
\hline
\end{tabular}

The compound $\mathbf{2 c}$ crystallizes in the orthorhombic space group $\mathrm{P} 2_{1}$. The molecular structure of the compound $\mathbf{2 c}$ is shown in Fig. 4. There are four crystallographically independent molecules in the asymmetric unit different from 2a and 2b. The selected bond lengths and bond angles are listed in Table-6. The $\mathrm{C}-\mathrm{Cl}$ bond distances are in the range of 1.736(3)1.743(3) $\AA$. There are lack of inetermolecular hydrogen and $\pi-\pi$ stacking interactions, the molecular strucuture is is stablilized by van der Waals forces.

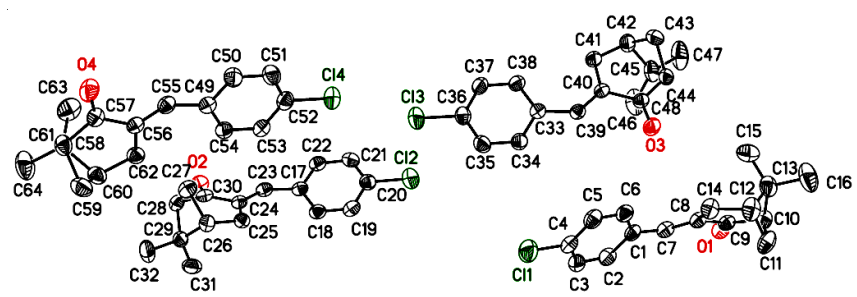

Fig. 4. Molecular structure of the compound 2c (hydrogen atoms were omitted for clarity)

\section{Conclusion}

Three (1R, 5R)-(-)3-arylideneopinone derivatives (2a, 2b and $\mathbf{2 c}$ ) were successfully synthesized and characterized by single-crystal X-ray diffraction method. These compounds crystallize on three different space group belongs P $2{ }_{1} 2{ }_{1} 2_{1}$, P32 and P21 respectively. There is also a strong intermolecular $\mathrm{O}-\mathrm{H}$... O hydrogen bond between the carbonyl and hydroxy groups in $\mathbf{2} \mathbf{a}$ and $\mathbf{2} \mathbf{b}$, but there are lack of inetermolecular hydrogen in $\mathbf{2 c}$.

\section{ACKNOWLEDGEMENTS}

The authors acknowledged the financial support received from Forestry Public Sector Research Fund of State Forestry Administration of China (Grant No. 201104015) and from the Committee of National Natural Science Foundation of China (Grant No. 30972316 and No. 31170538), and a project funded by the Priority Academic Program Development of Jiangsu Higher Education institutions. Thanks are also due to Mr. Lai Jie who provided the starting material.

\section{REFERENCES}

1. E. Chatelain and B. Gabard, Photochem. Photobiol., 74, 401 (2001).

2. M. Wlaschek, L. Tantcheva-Poor, L. Naderi, W. Ma, L.A. Schneider, Z. Razi-Wolf, J. Schüller and K. Scharffetter-Kochanek, J. Photochem. Photobiol. B, 63, 41 (2001).

3. K.C. Farmer and M.F. Naylor, Ann. Pharmacother, 30, 662 (1996).

4. C. Couteau, A. Faure, J. Fortin, E. Paparis and L.J.M. Coiffard, J. Pharm. Biomed. Anal., 44, 270 (2007).

5. J. Hojerova, A. Medovcikova and M. Mikula, Int. J. Pharm., 408, 27 (2011).

6. N. Tarras-Wahlberg, G. Stenhagen, O. Larko, A. Rosén, A.M. Wennberg and O. Wennerström, J. Invest. Dermatol., 113, 547 (1999).

7. A. Deflandre, S. Forestier, A. Lagrange, G. Lang and C. Moire, US Patent 5000961 A (1991)

8. L.M. Yuan and D.Q. Deng, J. Dermatol. Venereal., 31, 20 (2009).

9. G.M. Sheldrick, SHELXTL Version 5.10 (Bruker AXS Inc., Madsion), (1997).

10. A.P. Bozopoulos, C.A. Kavounis, G.S. Stergioudis and P. J. Rentzeperis, Z. Kristallogr., 187, 97 (1989). 